\title{
Heat Transfer Coefficient Analysis of the Chamber of Cyprus Turkish Architects Office Building on the Zahra Street in the Walled City of Nicosia in Cyprus
}

\author{
Yasemin Mes da \\ Department of Architecture, Cyprus International University, Nicosia, Cyprus-North Cyprus
}

\begin{abstract}
This study analyses and calculates the heat transfer coefficient values of the 134 years old historical building in the walled city of Nicosia. The build ing is the typical example of the Traditional Turkish House and built by the traditional adobe materials and stones. The ceiling, external walls, roof and the windows of the building were analysed to estimate the heat transfer coefficient values of the house and to demonstrate the influence of the climate conditions of Cyprus on the physics of the building. The estimated $\mathrm{U}$ values of this old building are, $0,49 \mathrm{~W} / \mathrm{m}^{2} \mathrm{~K}$ for the exterior adobe walls, $0,27 \mathrm{~W} / \mathrm{m}^{2} \mathrm{~K}$ for the ceiling, $0,13 \mathrm{~W} / \mathrm{m}^{2} \mathrm{~K}$ for the roof and $2,0 \mathrm{~W} / \mathrm{m}^{2} \mathrm{~K}$ for the windows. The comparison of these values with the modern concrete build ing under the same climatic conditions demonstrate that the adobe building provides better inner environment for the house life and also decreases the energy costs for the thermal insulation.
\end{abstract}

Keywo rds The Walled City of Nicosia, Traditional Turkish House, Heat Transfer Coefficient, Stone-Adobe Building, Cultural Heritage, Mediterranean Climate

\section{Introduction}

The contemporary build ings which built by many modern techniques and the materials do not provide natural inner environment for house life. In particular, heating and cooling of houses by using the electrical machines (e.g. ventilator) effect this negatively. Comparis on of the contemporary buildings with the ancient build ings reveal that usage of the traditional materials in the old buildings provide natural inner environment, in which requirements for heating or cooling of houses reduce respectively.

In this study Chamber of Cyprus Turkish Architects Office building was analysed which was built during the Ottoman rule on the island. The building was examined to calculate the heat transfer coefficient values under the Mediterranean climate conditions. And the result was compared with the modern concrete building from the climatically same area.

The Mediterranean Climate is characterized by hot and dry summers and mild to cool, wet winters. The coldest mo $\mathrm{nth}$ on the island of Cyprus is January and the hottest month is July. The average temperature for January is $15.5{ }^{\circ} \mathrm{C}$ and July is $37.2^{\circ} \mathrm{C}$.

The result of the calculations of the heat transfer

* Corresponding author:

yaseminmesda@gmail.com (Yasemin Mesda)

Published online at http://journal.sapub.org/arch

Copyright (C) 2012 Scientific \& Academic Publishing. All Rights Reserved coefficients values of both the adobe and the modern concrete buildings demonstrate that the adobe buildings have many advantages in the places where Mediterranean Climate is dominant.

This paper consists of nine sections. In the second section, after the introduction, the history of the Cyprus Island and Nicosia are explained. In section three, the location and history of the Chamber of Cyprus Turkish Architects Office building a re described, followed by the section four which describes the architectural characteristic of the building. The theoretical framework of the study is explained in section five and the method of the study is described in section six. In section seven, the heat transfer coefficient analyses are done. A comparison of this historical building with a modern build ing is in section eight. Section nine is the conclusion part of the paper.

\section{Short Historical Background of the Island of Cyprus and Nicosia}

Cyprus is the third largest island in the Mediterranean Sea after Sicily and Sardinia. Many different civilizations were lived on the Cyprus Island both before and after Christ through the history. The history of Cyprus had been started in $10000 \mathrm{BC}$. Nicosia was began to use as a capital city since $600 \mathrm{AD}[1]$. The city is surrounded by $8-10$ meters high stone walls which were built during the Venetian period on the island between 1489 and 1571 and provided a 
safety location for both the citizens and the king of the island to live.

Today, Nicosia is the centre of the govern ment as well as the main business city of the island. It is the only divided capital city in the world (after the demolition of the Berlin Wall) and this division is the most important feature of the city.

The cultural heritage of the old walled city of Nicosia is very rich due to the great number of architectures that left from the ancient civilizations.

The earliest traces of the permanent settlements in Nicosia belong to the Chalcolithic and Bronze Ages. Following these periods, Nicosia was inhabited by Phoenicians, Assyrians, Persians, Egyptians and later by the people of Archaic (750-475 BC), Classic, Hellen istic (325-50 BC) and Roman (50 BC- 395 AD) Periods[2]. Despite all the evidences obtained, it is not possible to determine the size and boundaries of the ancient walled city of Nicosia exactly. This is because, probably contemporary buildings were built on the traces of the old settlements in the region. Succeeding the Roman Period on the island, Byzantine (395-1191), Lusignan (1191-1489), Venetian (1489-1571), Ottoman (1571-1878) and British (1878-1960) ruled the island. The architectural examples of these people can be seen in the walled city of Nicosia today. Following the end of the British rule on the is land, the Republic of Cyprus was established in 1960 both by the Greek and Turkish Cypriots, in which both communities have their own separate $\mathrm{Mu}-$ nicipality as a 'Nicosia Greek Municipality' and 'Nicosia Turkish Municipality'. The peaceful time of the Republic of Cyprus was lasted very short by the inter-communal conflicts, which, at the end led to the division of the island by the Green Line in 1974. The southern part of the Green Line mainly inhabited by the Greek Cypriots and the northern part of it inhabited mostly by the Turkish Cypriots. The Figure 1 shows the division of the walled city of Nicosia by the Green Line.

\section{The Location and History of the Chamber of Cyprus Turkish Archi- tects Office Building}

The building is located in the Arabahmet District in the walled city of northern Nicosia (Fig. 1). The history of this district goes back to the Lusignan period (1192-1489). Arabahmet District was a buffer zone during the inter-communal conflict years between 1963 and 1974. For this reason, lots of buildings got damage during these clashes. There are three main streets and many narrow streets in the Arabahmet District. The Zahra Street, the Tanzimat Street and the Viktorya Street (Şehit Salahi Şevket Sokak) are the main streets of this district. This region is taken its' name by the commander Arabahmet Pasha who controlled the Ottoman army during their rules on the island. Latin, Ottoman, Greek, Maronite and Arme- nian societies were lived in this region. The two and three storey historical stone and adobe houses which also have cumbas (projections) are located in these narrow streets (Figs. 2 and 3). The high courtyard walls of the buildings represent the importance of the privacy for the ancient citizens of the city. All the buildings are in human size and they are so lovely in this district. They reflect the strong history of the old periods.

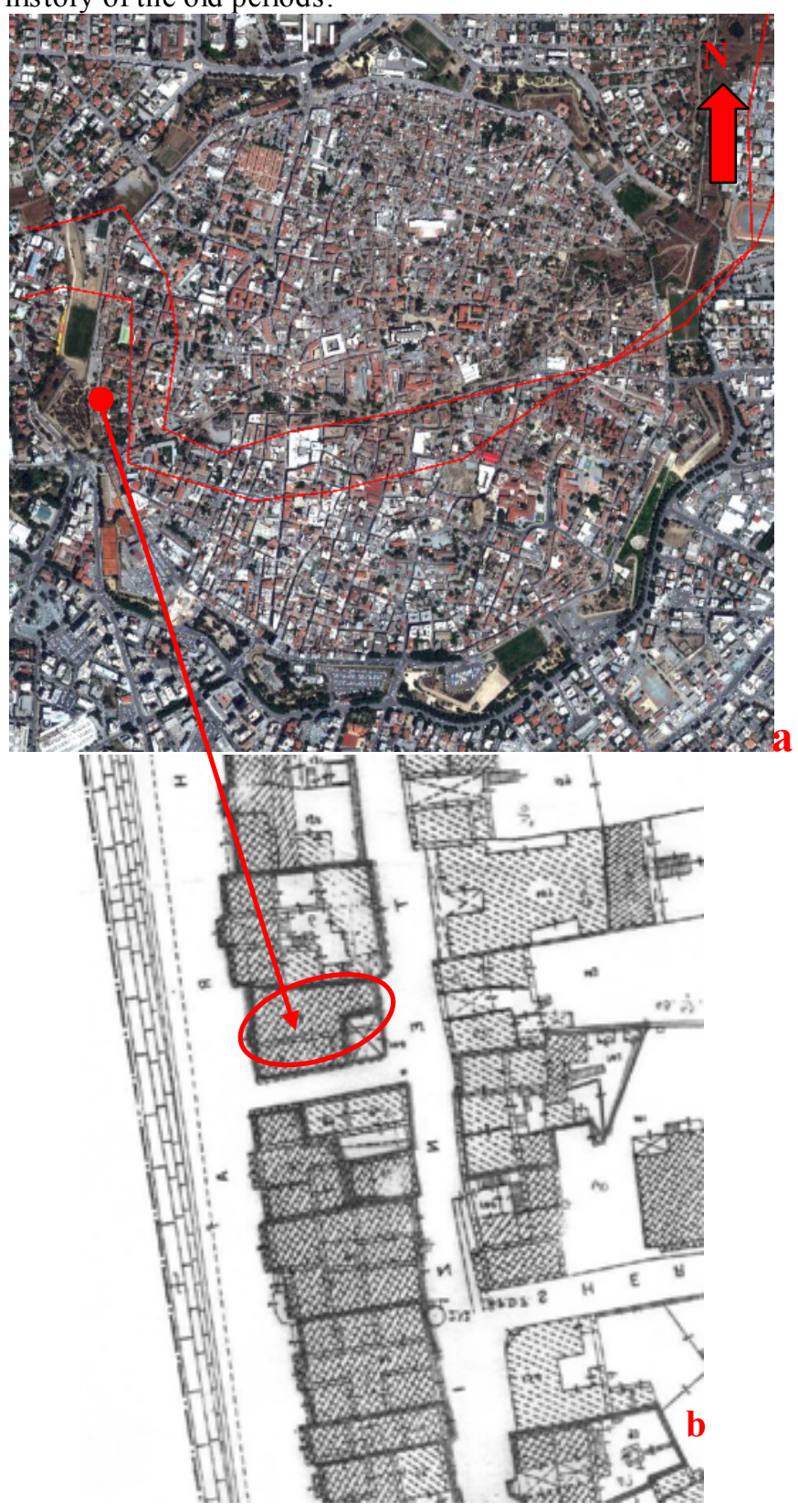

Figure 1. a) View of the walled city of Nicosia; b) the location of the Chamber of Cyprus Turkish Architects Office Building[6,7]

Arabahmet District was inhabited by the rich families during the Ottoman Period. However, it was abandoned in the 1960's due to the intercommunal violence and its inhabitants moved outside of Nicosia. After this abandonment the buildings of the district started to demolish through the years. The restoration works were started in 1990's in this district and many buildings were gained back to the society. 


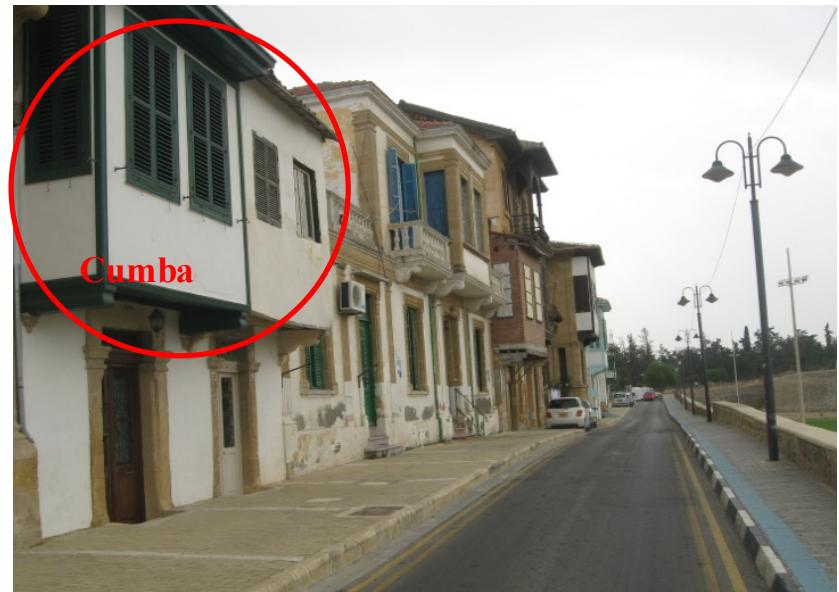

Figure 2. View of the Zahra Street and its houses (Mesda, 2012)

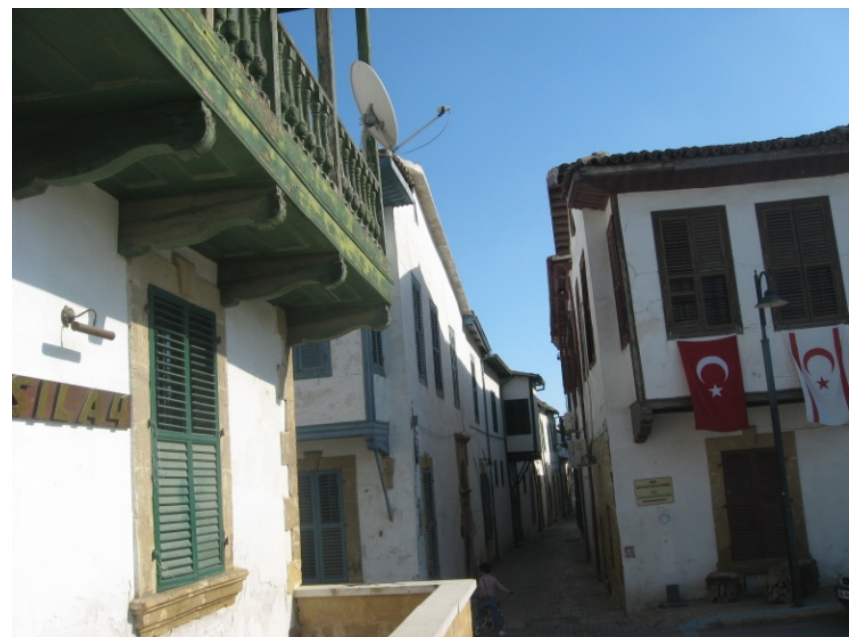

Figure 3. View of the narrow street in the Arabahmet district (Mesda, 2012)

The Chamber of Cyprus Turkish Architects Office building is located on the Zahra Street. The location of this street is very important because there are no other buildings in front of it (Fig. 2) and also it is located on the direction of the north-western wind. Therefore, it gets the north-western wind directly which provide natural air conditioning for the buildings of the street. The entrance facade of the Chamber of Cyprus Turkish Architects Office building is located on the direction of the western wind which is the main wind direction on the is land.

The build ing was constructed at the end of the Ottoman Period on the island. It has about 134 years historical background. The plan, façade characteristics and the construction techniques of the building represent the Traditional Turkish House characteristics. This building was used as a house in the old periods. It is a two storey building and a corner building (Fig. 4). It has two facades due to the adjacent houses on its eastern and northern sides. The ground floor was constructed with the stone material and the first floor was constructed with the adobe materials.

Ahmet Behzat Aziz Beyli is known as the owner of this building. The building was in the very bad condition after the abandonment (Fig. 5a). However, it was restored by using many modern construction techniques and the un- damaged elements of the house were placed again very carefully[8] during the restoration project (Fig. 5b) in 1995.

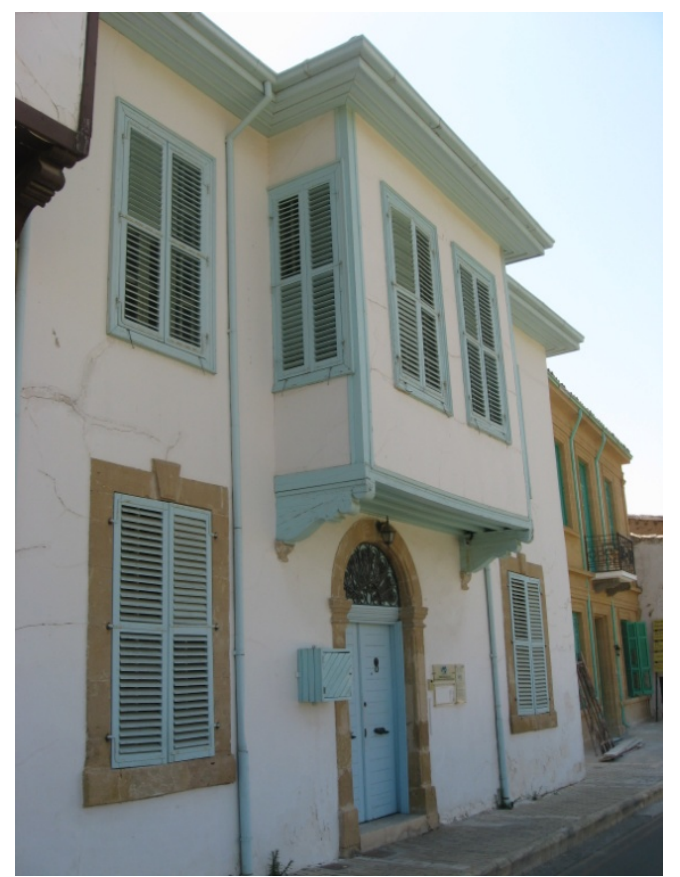

Figure 4. The Chamber of Cyprus T urkish Architects Office building (Mesda, 2012)
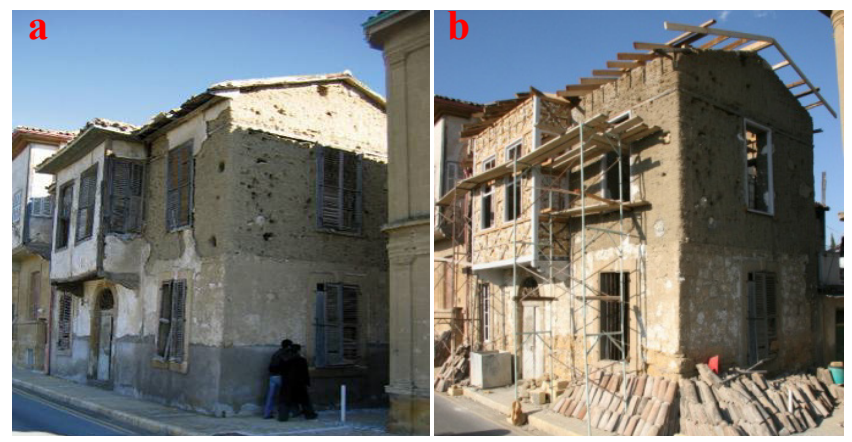

Figure 5. View of the building before (a) and during the restoration (b) $[8]$

\section{Architectural Characteristics of the Building}

\subsection{Plan Char acteristics}

The plan characteristic of the build ing is typical Turkish house plan type. This house is a two storey building. In the original plan, the service spaces are located on the ground floor; the living spaces are located on the first floor. Today, the sofa, kitchen, library room and toilets are located on the ground floor; the second sofa and the library room, meeting room and the archive are located on the first floor. In total, this building has eight rooms. Four rooms a re on the ground floor and four rooms are on the first floor.

The entrance of the building is provided by the sofa or main entrance hall on the west side. Transitions to the service spaces and to the rooms are provided by the main entrance hall. The $U$ shaped staircase provides the entrance to 
the first floor. It is located in the inner sofa (hall). It was highly damaged but during the restoration works it was repaired. Firstly, the steel structure was constructed and then the wooden material was used to cover the steps and risers.

The main room is located on the first floor. This room is an elaborate room and used for the guests in the Traditional Turkish Houses during the Ottoman Period. The arrangements of the first floor's spaces resemble the ground floor's space arrangement. It reflects the decoration of the Ottoman architecture. Today, this space is used as a study and waiting room. The other three rooms are used as meeting, library and archive rooms. The ground and first floor plans can be seen in the Figures 6 and 7.

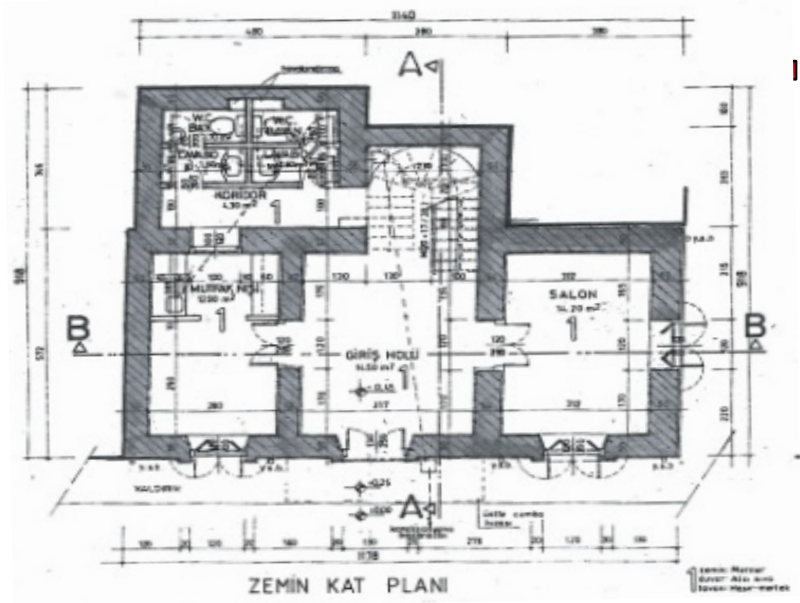

Figure 6. Ground floor plan of the building[8]

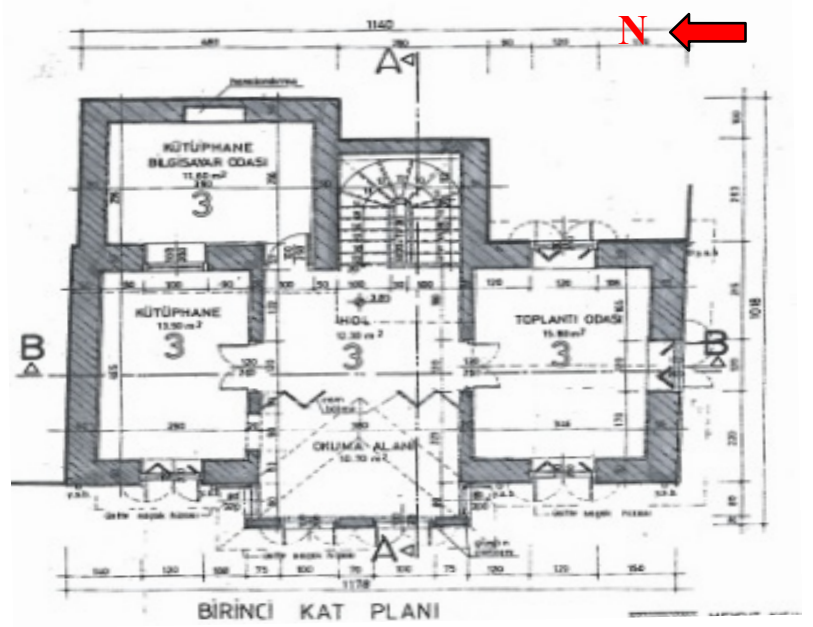

Figure 7. First floor plan of the building[8]

\subsection{Facade Characteristics}

This building has two facades because other buildings are located on the north and east sides of the building. The main entrance facade is on the west side. The Ottoman style, arched entrance door is located on this facade. The facades are simple and human scale. There is no ornamentation on the facades. The windows are all same. They are double winged shuttered windows. Lattice windows are not used on the facades of this building. Cumba was constructed on the west entrance facade. The eave of the building has no decoration. Only the cut yellow stone materials were used to decorate the entrance door and the windows of the ground floor (Figs. 8, 9).

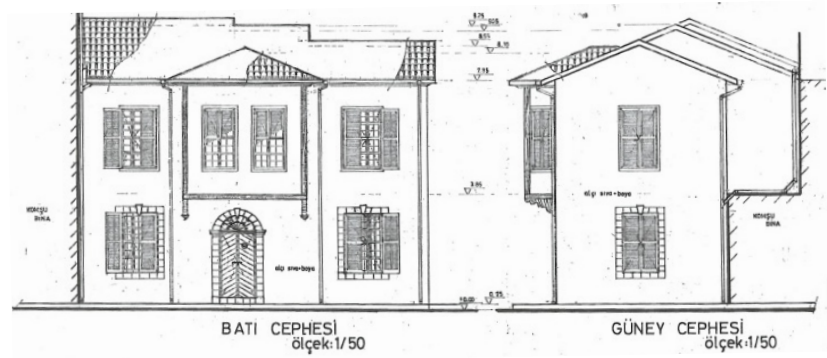

Figure 8. Drawings of the west and south elevation of the building[8]

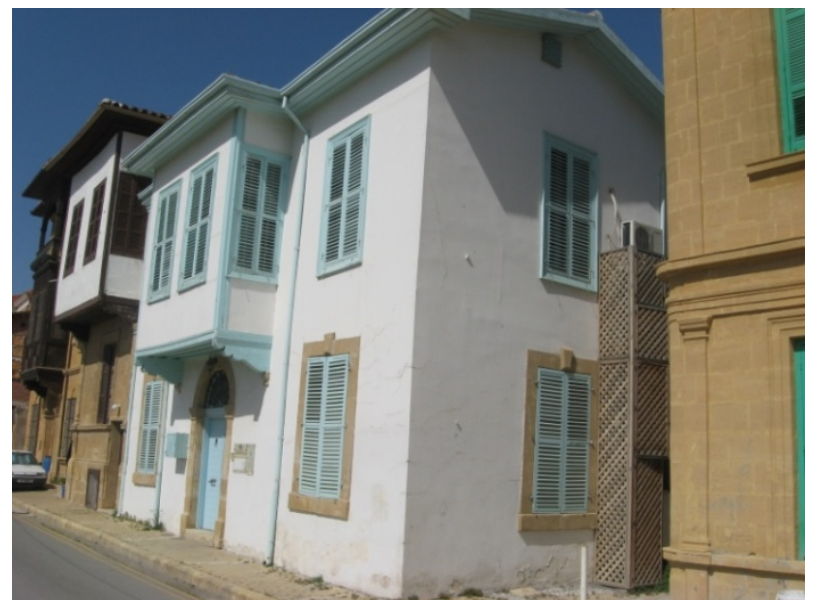

Figure 9. View of the west and south facades of the building (Mesda, 2012)

\subsection{Construction Techniques and Materials}

Adobe material was used for the construction of this building. This material is a traditional build ing material of the Cyprus Island, particularly, Mesaoria (Mesarya) region. It has environmental and ecological advantages, and also it is both sustainable and contemporary material. The adobe material has been used since the ancient times for the house constructions. Usage of the adobe build ing materials provide a good condition and comfortable living environment inside the houses. In addition, this material can be recycled.

Beside the adobe material, the natural stones were also used in the construction of the building. The natural stones were used to build the walls of the ground floor. The first floor was constructed with the adobe material (Figs. 4, 5). Wall thicknesses vary between 15 to $65 \mathrm{~cm}$. The walls were plastered with gypsum plaster materials. Gypsum was used to plaster both the inner and outer surfaces of the walls and it also serves as a filling material for the wooden lath. Moreover, because it is a natural material, the gypsum plaster allows the adobe, the stone, and the wood to contact with the air and enables them to have a long life. No concrete was used in the construction of this building.

The Baghdadi construction technique was used to build the cumba of the house. First of all, the timber framing elements were constructed and stone materials were filled 
inside these frames. The bay window was built in the lath system with the windows which have shutters and a guillotine systems. The rest of the windows were built with shutters and an opening glass system. The floor of the first floor was made of local materials in which marble and wood were used. The ceiling was covered with a straw mat[8]. The detail of the roof can be seen in Figure 10. The wooden suspended ceiling roof was constructed during the restoration works. The tiles are aligned on the roof.

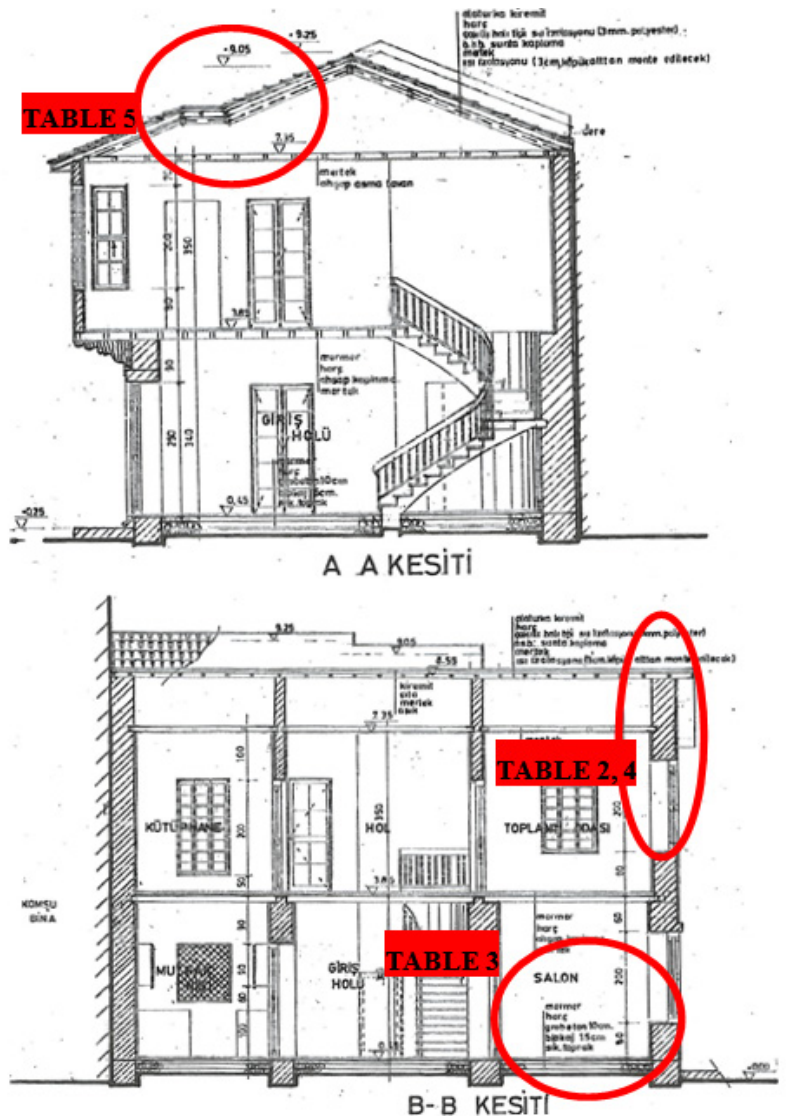

Figure 10. Sections of the building[8]

\section{Theoretical Framework}

The natural energy sources in the world are depleted very quickly. The thermal insulation provides economical advantages both for the families and the countries as well as it has a good impact on the buildings and the environment. In Turkey, the ministry of Public Works and Energy have implemented a new rule in 1998 under the title of 'thermal insulation rules on the buildings (TS 825)' which became legally compulsory for all the buildings that are going to be built after May 2000[9].

To provide the thermal insulation in the buildings, the required heat transfer coefficients values of the different parts of the building for the different geographical regions of Turkey were estimated. Table 1 indicates the estimated heat transfer coefficient values of roof, window, ceiling and walls of buildings for the four different regions of Turkey.

Due to the close relationship of Northern Cyprus with the mainland Turkey and the same climatic conditions of Cyprus with the Mediterranean region of Turkey, the estimated values of TS 825 are applied in the Northern Cyprus as well.

Table 1. Recommended heat transfer coefficients (U values) for the different regions of Turkey ${ }^{1}$ (T S 825)

\begin{tabular}{|c|c|c|c|c|}
\hline \multicolumn{5}{|c|}{$\begin{array}{l}\text { Recommended heat transfer coefficients (U values) for different } \\
\text { regions T S } 825[14]\end{array}$} \\
\hline & $\begin{array}{c}\mathbf{U}_{\text {wall }} \\
\left(\mathbf{W} / \mathbf{m}^{2} \mathbf{K}\right. \\
)\end{array}$ & $\begin{array}{l}\mathbf{U}_{\text {ceiling }} \\
\left(\mathbf{W} / \mathbf{m}^{2} \mathbf{K}\right)\end{array}$ & $\begin{array}{c}\mathbf{U}_{\text {roof }} \\
\left(\mathbf{W} / \mathbf{m}^{2} \mathbf{K}\right)\end{array}$ & $\begin{array}{l}\mathbf{U}_{\text {window }} \\
\left(\mathbf{W} / \mathbf{m}^{2} \mathbf{K}\right)\end{array}$ \\
\hline Region 1 & 0,80 & 0,50 & 0,80 & 2,8 \\
\hline Region 2 & 0,60 & 0,40 & 0,60 & 2,6 \\
\hline Region 3 & 0,50 & 0,30 & 0,45 & 2,6 \\
\hline Region 4 & 0,40 & 0,25 & 0,40 & 2,4 \\
\hline $\begin{array}{c}\text { Alker } \\
\text { structure } \\
\text { in } \mathrm{Cy}- \\
\text { prus[9] }\end{array}$ & $\begin{array}{c}0,45-0,5 \\
0\end{array}$ & 0,32 & 0,43 & 2,2 \\
\hline $\begin{array}{c}1 / \mathbf{a}_{\mathrm{i}} \\
\mathbf{m}^{2} \mathbf{W} / \mathbf{K} \\
1 / \mathbf{a}_{\mathrm{e}} \\
\mathbf{m}^{2} \mathbf{W} / \mathbf{K}\end{array}$ & $\begin{array}{l}0,13 \\
0,04\end{array}$ & $\begin{array}{c}0,17 \\
0\end{array}$ & $\begin{array}{l}0,13 \\
0,04\end{array}$ & - \\
\hline
\end{tabular}

The 'thermal insulation rules on the building' also trig-gered the studies about the condition of the thermal insula-tion on the old buildings. Many analytical studies have been conducted to estimate the values of the heat transfer coefficient on the old constructions and compare them with the new buildings to understand the differences, in which this study is one of them.

\section{Methods}

The heat transfer coefficient values of the roof, windows, external walls and the ceiling of the build ing were calculated in this study. Firstly, the thickness of all the materials that used in the construction of the roof, windows, ceiling and the walls were estimated. Then, the standard values of the each material were found from the TS 825 's table and the thickness values of the house's materials were divided into these values and the results of this process were applied to the formula below.

$\mathrm{U}_{\mathrm{o}}=1 /\left(1 / \mathrm{a}_{\mathrm{i}}+\mathrm{d}_{1} / \lambda_{1}+\mathrm{d}_{2} / \lambda_{2}+\mathrm{d}_{3} / \lambda_{3}+\ldots+\mathrm{d}_{\mathrm{n}} / \lambda_{\mathrm{n}}+1 / \mathrm{ae}_{\mathrm{ae}}\right)$

$\mathrm{U}_{\mathrm{o}}$ : The overall heat transfer coefficient of the opaque component $\mathrm{W} / \mathrm{m}^{20} \mathrm{C}$.

1 Region 1: Adana, Aydın, Mersin, Osmaniye, Antalya Hatay, Izmir. Region 2: Sakarya, Çanakkale, Kahraman Maraş, Rize, Trabzon, Adıyaman, Denizli, Kilis, Samsun, Yalova, Amasya, Diyarbakır, Kocaeli, Siirt, Zonguldak, Balikesir, Edirne, Manisa, Sinop, Düzce, Bartın, Gaziantep, Mardin, Şanlıurfa, Batman, Giresun, Muğla, Şırnak, Bursa, Istanbul, Ordu, Tekirdağ.

Region 3: Afyon, Burdur, Karabük, Malatya, Aksaray, Çankırı, Karaman, Nevşehir, Ankara, Çorum, Kirikkale, Niğde, Artvin, Elazı̆̆, Kırklareli, Tokat, Bilecik, Eskişehir, Kırşehir, Tunceli, Bingöl, Iğdır, Konya, Uşak, Bolu, Isparta, Kütahya.

Region 4: Ağn, Erzurum, Kayseri, Ardahan, Gümüşhane, Muş, Bayburt, Hakkâri, Sivas, Bitlis, Kars, Van, Erzincan, Kastamonu, Yozgat. 
$\mathrm{a}_{\mathrm{i}}, \mathrm{a}_{\mathrm{e}}$ : Internal and external surface heat transfer coefficients, $\mathrm{W} / \mathrm{m}^{20} \mathrm{C}$.

$\mathrm{d}_{1}, \mathrm{~d}_{2}, \ldots, \mathrm{d}_{\mathrm{n}}$ : Thickness of the layers constituting the opaque component, $\mathrm{m}$.

$\lambda_{1}, \lambda_{2}, \ldots, \lambda_{\mathrm{n}}$ : Thermal conductivities of the layers constituting the opaque component $\mathrm{W} / \mathrm{m}^{2}{ }^{\circ} \mathrm{C}$.

After these calculations the correlation of the house materials to the TS 825 values can be tested by using the table 1.

\section{Heat Transfer Coefficient Analysis of the Old Building According to the its Building Physics Conditions}

Four different heat transfer coefficient values were calculated in this section. The estimated value for the exterior adobe walls is $0,49 \mathrm{~W} / \mathrm{m}^{2} \mathrm{~K}$, for the ceiling is 0,27 $\mathrm{W} / \mathrm{m}^{2} \mathrm{~K}$, for the roof $0,31 \mathrm{~W} / \mathrm{m}^{2} \mathrm{~K}$ and for the windows is $2,0 \mathrm{~W} / \mathrm{m}^{2} \mathrm{~K}$. The calculation spaces can be seen in Figure 10.

The usage of the adobe materials in this building is very significant for the heat transfer coefficient values. In particular, the thick adobe wall of the first floor has a big impact on the result. Because, it controls the heat transfer and provide the heat insulation for the house. Therefore, bio-climatic comfort are available in the build ing both in the summer and winter seasons without a need for the artificial heat insulation.

The result of these four calculations that are shown below demonstrate that the heat transfer coefficient values of the building comply with the Region 1 (Mediterranean Climate region) regulations of the TS 825 which is shown in table 1 .

Table 2. Calculation of the heat transfer coefficient values for the south facade and the exterior wall

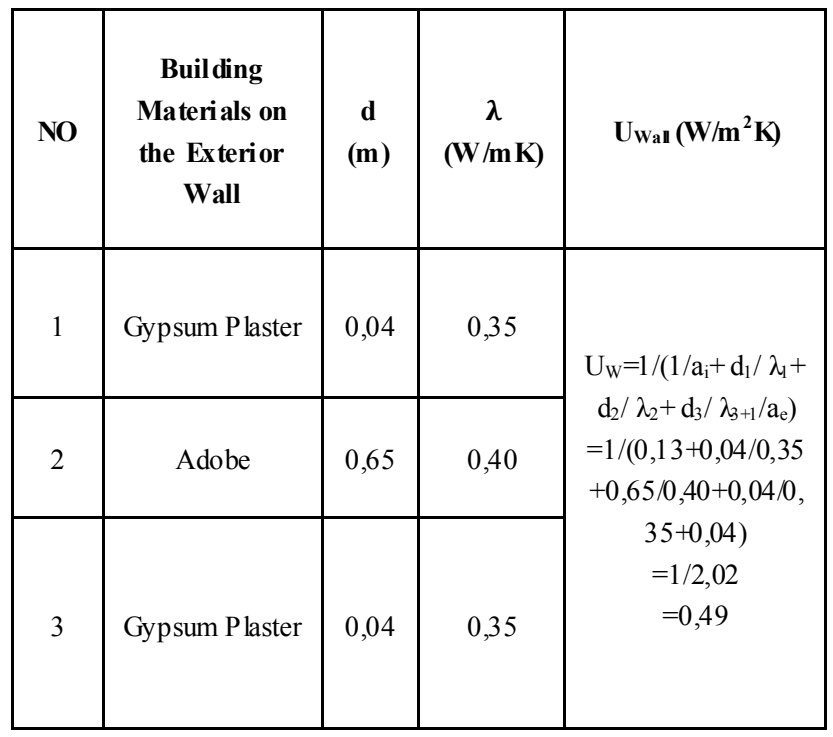

$0,80 \geq 0,49$ : It is suitable value for exterior wall.
Table 3. Calculation of the heat transfer coefficient values for the ceiling

\begin{tabular}{|c|c|c|c|c|}
\hline NO & $\begin{array}{l}\text { Building } \\
\text { Materials on } \\
\text { the Ceiling }\end{array}$ & $\begin{array}{c}d \\
(\mathrm{~m})\end{array}$ & $\begin{array}{c}\lambda \\
(W / m K)\end{array}$ & $\mathbf{U}_{\text {Ceiling }}\left(\mathbf{W} / \mathbf{m}^{2} \mathbf{K}\right)$ \\
\hline 1 & Silt & 0,15 & 2,1 & \multirow{6}{*}{$\begin{array}{c}\mathrm{U}_{\mathrm{W}}=1 /\left(1 / \mathrm{a}_{\mathrm{i}}+\mathrm{d}_{1} / \lambda_{1}+\right. \\
\mathrm{d}_{2} / \lambda_{2}+\mathrm{d}_{3} / \lambda_{3}+\mathrm{d}_{4} / \lambda_{4}+ \\
\left.\mathrm{d}_{5} / \lambda_{5}+1 / \mathrm{a}_{\mathrm{e}}\right) \\
=1 /(0,17+0,15 / 2,1+0 \\
, 15 / 0,70+0,10 / 1,74+ \\
0,06 / 0,02+0,03 / 1,40 \\
+0,02 / 3,5+0) \\
=1 / 3,587 \\
=0,27\end{array}$} \\
\hline 2 & $\begin{array}{r}\text { Pumice } \\
\text { Gravel } \\
\end{array}$ & 0,15 & 0,70 & \\
\hline 3 & Concrete & 0,10 & 1,74 & \\
\hline 4 & $\begin{array}{c}\text { Glass Fiber } \\
\text { Foam }\end{array}$ & 0,06 & 0,04 & \\
\hline 5 & Mortar & 0,03 & 1,40 & \\
\hline 6 & Marble & 0,02 & 3,5 & \\
\hline
\end{tabular}

$0,50 \geq 0,27$ : It is suitable value for the ceiling.

Table 4. Calculation of the heat transfer coefficient values for the roof

\begin{tabular}{|c|c|c|c|c|}
\hline NO & $\begin{array}{c}\text { Buil ding } \\
\text { Materials on } \\
\text { the Roof }\end{array}$ & $\begin{array}{c}\mathrm{d} \\
(\mathrm{m})\end{array}$ & $\begin{array}{c}\lambda \\
(W / m K)\end{array}$ & $\mathbf{U}_{\text {Roof }}\left(\mathbf{W} / \mathbf{m}^{2} \mathbf{K}\right)$ \\
\hline 1 & $\begin{array}{l}\text { Thermal } \\
\text { Insulation } \\
\text { Smooth } \\
\text { Boards }\end{array}$ & 0,05 & 0,02 & \multirow{4}{*}{$\begin{array}{c}\mathrm{U}_{\mathrm{W}}=1 /\left(1 / \mathrm{a}_{\mathrm{i}}+\mathrm{d}_{1} / \lambda_{\mathrm{1}}+\right. \\
\mathrm{d}_{2} / \lambda_{2}+\mathrm{d}_{3} / \lambda_{3}+\mathrm{d}_{4} / \\
\left.\lambda_{4}+1 / \mathrm{a}_{\mathrm{e}}\right) \\
=/(0,13+0,05 / 0,02+0, \\
16+0,05 / 0,13+ \\
0,02 / 1,40+0,04)=1 / 3, \\
22 \\
=0,31\end{array}$} \\
\hline 2 & $\begin{array}{c}\text { Thermal } \\
\text { Resistance of } \\
\text { Air Spaces 1/ } \\
\quad \lambda \\
\end{array}$ & \multicolumn{2}{|c|}{$\begin{array}{l}0,16 \text { for } 15 \mathrm{~cm} \\
\text { thickness of } \\
\text { horizontal warm } \\
\text { surface down }\end{array}$} & \\
\hline 3 & $\begin{array}{c}\text { Platen } \\
\text { Pressed } \\
\text { Chipboard } \\
\end{array}$ & 0,05 & 0,13 & \\
\hline 4 & Mortar & 0,02 & 1,40 & \\
\hline
\end{tabular}

$0,80 \geq 0,31$ : It is suitable value for roof.

Table 5. Calculation of the heat transfer coefficient values for the windows (TS 2164)[15]

\begin{tabular}{|c|c|c|}
\hline NO & $\begin{array}{c}\text { Buil ding Materials on the Win- } \\
\text { dow }\end{array}$ & $\begin{array}{c}\mathbf{U}_{\text {Window }} \\
\left(\mathbf{W} / \mathbf{m}^{\mathbf{2}} \mathbf{K}\right)\end{array}$ \\
\hline 1 & $\begin{array}{c}\text { Wooden Sash } \\
\text { Double Glazed Windows with } \\
\text { Low-E Coating (Air Gap }=12 \mathrm{~mm})\end{array}$ & $\mathrm{U}_{\mathrm{Wi}=2,0}$ \\
\hline
\end{tabular}

$2,8 \geq 2,0$ : It is suitable value for window.

\section{Discussion}

In this section, the heat transfer coefficient values of the Chamber of Cyprus Turkish Architects Office building was compared with the modern concrete building from the same climate region (Region 1) to see the differences in the heat transfer coefficient values and to show the advantages of the adobe buildings over the modern build ing materials. 


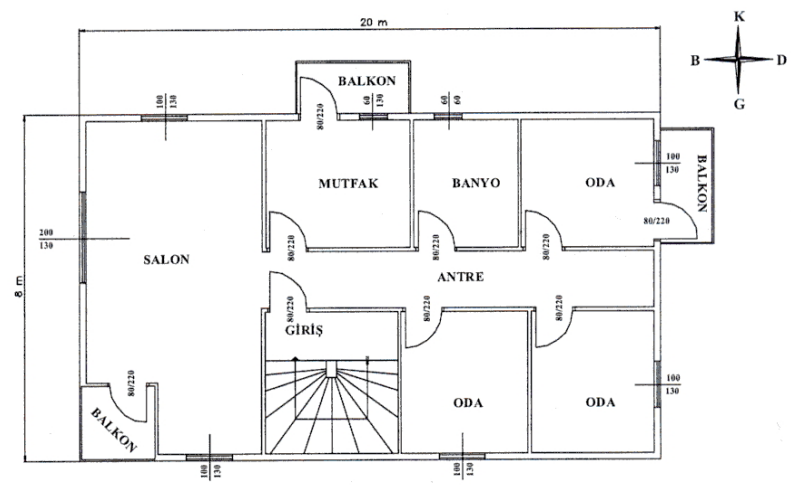

Figure 11. Ground plan of the contemporary building[16]

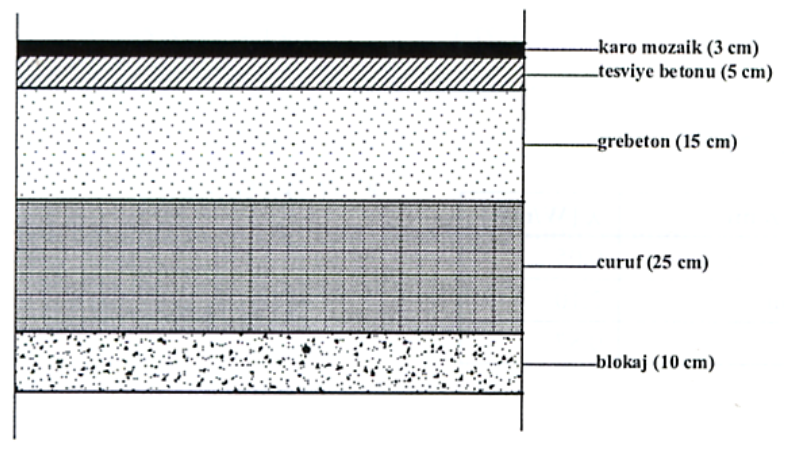

Figure 12. Ceiling detail of the contemporary building[16]

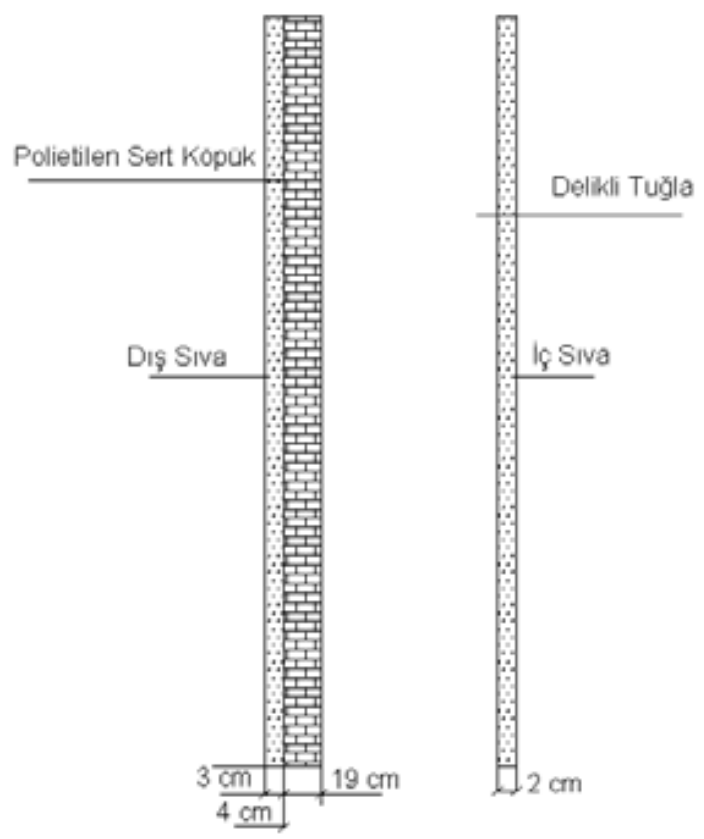

Figure 13. Wall detail of the contemporary building[16]

The heat transfer coefficient values of the exterior walls, ceiling, roof and the windows of the modern building and their comparison with the Chamber of Cyprus Turkish Architects Office building are shown below in the tables 6-9.
Table 6. Calculation of the heat transfer coefficient for exterior walls

\begin{tabular}{|c|c|c|c|c|}
\hline NO & $\begin{array}{c}\text { Building } \\
\text { Materials on } \\
\text { the Exterior } \\
\text { Wall }\end{array}$ & $\begin{array}{c}\mathrm{d} \\
(\mathrm{m})\end{array}$ & $\begin{array}{c}\lambda \\
(W / \mathbf{m} K)\end{array}$ & $\mathbf{U}_{\mathrm{Wall}}\left(\mathbf{W} / \mathbf{m}^{2} \mathbf{K}\right)$ \\
\hline 1 & $\begin{array}{c}\text { Exterior Plas- } \\
\text { ter }\end{array}$ & 0,02 & 0,870 & \multirow{4}{*}{$\begin{array}{c}\mathrm{U}_{\mathrm{W}}=1 /\left(1 / \mathrm{a}_{\mathrm{i}}+\mathrm{d}_{1} /\right. \\
\lambda_{1}+\mathrm{d}_{2} / \lambda_{2}+\mathrm{d}_{3} / \\
\left.\lambda_{3+1} / \mathrm{a}_{\mathrm{e}}\right) \\
=1 /(0,13+0,02 / 0,8 \\
70+0,19 / 0,450+0,0 \\
4 / 0,035+0,03 / 1,40 \\
+0,04) \\
=1 / 1,77 \\
=0,56\end{array}$} \\
\hline 2 & $\begin{array}{c}\text { Horizontal Air } \\
\text { Brick }\end{array}$ & 0,19 & 0,450 & \\
\hline 3 & $\begin{array}{l}\text { Polyurethane } \\
\text { Rigid Foam }\end{array}$ & 0,04 & 0,035 & \\
\hline 4 & $\begin{array}{c}\text { Exterior Plas- } \\
\text { ter }\end{array}$ & 0,03 & 1,40 & \\
\hline
\end{tabular}

$0,80 \geq 0,56$ : It is suitable value for exterior walls.

Table 7. Calculation of the heat transfer coefficient for ceiling

\begin{tabular}{|c|c|c|c|c|}
\hline NO & $\begin{array}{l}\text { Building } \\
\text { Materials on } \\
\text { the Ceiling }\end{array}$ & $\begin{array}{c}\text { d } \\
(\mathrm{m})\end{array}$ & $\begin{array}{c}\lambda \\
(W / m K)\end{array}$ & $\mathbf{U}_{\text {Ceiling }}\left(\mathbf{W} / \mathbf{m}^{2} \mathbf{K}\right)$ \\
\hline 1 & Concrete & 0,15 & 1,74 & \multirow{5}{*}{$\begin{array}{c}\mathrm{U}_{\mathrm{W}}=1 /\left(1 / \mathrm{a}_{\mathrm{i}}+\mathrm{d}_{1} / \lambda_{1}+\right. \\
\mathrm{d}_{2} / \lambda_{2}+\mathrm{d}_{3} / \lambda_{3}+\mathrm{d}_{4} / \lambda_{4}+ \\
\left.\mathrm{d}_{5} / \lambda_{5}+1 / \mathrm{a}_{\mathrm{e}}\right) \\
= \\
1 /(0,13+0,15 / 1,74+0, \\
25 / 0,23+0,10 / 0,70+0 \\
, 05 / 1,40+0,03 / 1,30+ \\
0) \\
=1 / 1,48 \\
=0,27\end{array}$} \\
\hline 2 & Mortar & 0,25 & 0,23 & \\
\hline 3 & $\begin{array}{l}\text { Pumice } \\
\text { Gravel }\end{array}$ & 0,10 & 0,70 & \\
\hline 4 & Slag & 0,05 & 1,40 & \\
\hline 5 & Mosaic & 0,03 & 1,30 & \\
\hline
\end{tabular}

$0,50 \geq 0,67$ : It is not suitable value for ceiling.

Table 8. Calculation of the heat transfer coefficient for roof

\begin{tabular}{|c|c|c|c|c|}
\hline NO & $\begin{array}{c}\text { Building } \\
\text { Materials on } \\
\text { the Roof }\end{array}$ & $\begin{array}{c}\mathrm{d} \\
(\mathrm{m})\end{array}$ & $\begin{array}{c}\lambda \\
(W / m K)\end{array}$ & $\mathbf{U}_{\text {Roof }}\left(\mathbf{W} / \mathbf{m}^{2} \mathbf{K}\right)$ \\
\hline 1 & $\begin{array}{l}\text { Thermal } \\
\text { Insulation } \\
\text { Smooth } \\
\text { Boards }\end{array}$ & 0,1 & 0,05 & \multirow{3}{*}{$\begin{array}{c}\mathrm{U}_{\mathrm{W}}=1 /\left(1 / \mathrm{a}_{\mathrm{i}}+\mathrm{d}_{1} / \lambda_{1}+\right. \\
\mathrm{d}_{2} / \lambda_{2}+\mathrm{d}_{3} / \lambda_{3}+\mathrm{d}_{4} / \\
\left.\lambda_{4}+1 / \mathrm{a}_{\mathrm{e}}\right) \\
=/(0,13+0,1 / 0,052 \\
+0,12 / 2,1+0,02 / \\
0,87+0,04)=1 / 2,24 \\
=0,44\end{array}$} \\
\hline 2 & $\begin{array}{l}\text { Reinforced } \\
\text { Concrete }\end{array}$ & 0,12 & 2,10 & \\
\hline 3 & Mortar & 0,02 & 0,87 & \\
\hline
\end{tabular}

$0,80 \geq 0,44$ : It is suitable value for roof. $\mathrm{UP}=2,8 \mathrm{~W} / \mathrm{m} 2{ }^{\circ} \mathrm{K}$

$2,8 \geq 2,8$ : It is suitable value for window. 
Table 9. Comparison heat transfer coefficients (U values) for different building

\begin{tabular}{|c|c|c|c|c|}
\hline \multicolumn{5}{|c|}{ Comparison heat transfer coefficients (U values) for different } \\
buildings \\
\hline $\begin{array}{c}\mathbf{U}_{\text {wall }} \\
\left(\mathbf{W} / \mathbf{m}^{2} \mathbf{K}\right. \\
)\end{array}$ & $\begin{array}{c}\mathbf{U}_{\text {ceiling }} \\
\left(\mathbf{W} / \mathbf{m}^{2} \mathbf{K}\right)\end{array}$ & $\begin{array}{c}\mathbf{U}_{\text {roof }} \\
\left(\mathbf{W} / \mathbf{m}^{2} \mathbf{K}\right)\end{array}$ & $\begin{array}{c}\mathbf{U}_{\text {window }} \\
\left(\mathbf{W} / \mathbf{m}^{2} \mathbf{K}\right)\end{array}$ \\
\hline $\begin{array}{c}\text { Turkish } \\
\text { Standart }\end{array}$ & 0,80 & 0,50 & 0,80 & 2,8 \\
\hline $\begin{array}{c}\text { Tradi- } \\
\text { tional Old } \\
\text { Building }\end{array}$ & 0,49 & 0,27 & 0,31 & 2,0 \\
\hline $\begin{array}{c}\text { Con tem- } \\
\mathbf{p o r a r y} \\
\text { Building }\end{array}$ & 0,56 & 0,67 & 0,44 & 2,8 \\
\hline $\begin{array}{c}\mathbf{1} / \mathbf{a}_{\mathbf{i}} \\
\mathbf{m}^{\mathbf{W}} / \mathbf{K} \\
\mathbf{1} / \mathbf{a}_{\mathbf{e}}\end{array}$ & 0,13 & 0,17 & 0,13 & \\
$\mathbf{m}^{\mathbf{2}} \mathbf{W} / \mathbf{K}$ & 0,04 & 0 & 0,04 & - \\
\hline
\end{tabular}

The big differences between the $U$ values of the two buildings can be seen from the tables above. All the U values of the historical building are s maller than the values of the modern building. This shows that adobe material has advantage over the concrete material in which bio-climatic environment can be provided inside the building without the need for artific ial heat insulation.

\section{Conclusions}

In this paper, the benefits of the adobe material usage in the constructions were emphasized, in which its advantages on many aspects were discussed. The calculations in this paper demonstrate that re-introduction of the adobe material in the construction sector will provide many benefits. Particularly, in the places where the Mediterranean Climate is dominant, the construction of the adobe buildings will reduce the energy costs (e.g electricity).

As can be seen from the above calculations, the concrete building requires artificial thermal insulation; therefore, compare to the adobe building requires more energy-cost to provide the demanded temperature in the building.

Moreover, the bio-climatic inner environment provided by the adobe building has a good impact on human health as well as less requirement of the artificial equipments for the thermal insulation provide ecological and economical advantages.

\section{ACKNOWLEDGEMENTS}

The author would like to thank Prof. Dr. Bilge Işık, Gülten Manioğlu and Türker Aktaç for their patient advice, critic is $m$ and discussion throughout the writing process.

\section{REFERENCES}

[1] Mesda, Y., 2012: Transformation of the Lusignan Houses in the Ottoman Period in the Walled Cities of Nicosia and Famagusta in Northern Cyprus, Lambert Academic Publishing, Saarbrücken, Germany.

[2] Georgiou, G., 2002, "The Necropolis of Agia Paraskevi revisited", RDAC, Cyprus.

[3] Arslangazi, H., 2007, Lefkoşa Kent Dokusunda Mimari Üsluplar, Doktora Tezi, T.C. Marmara Üniversitesi Türkyat Araştırmaları Enstitüsü Türk Sanatı Anabilim Dalı, İstanbul.

[4] www.pud.org.tr

[5] Binalarda Isı Yalıtımı Yönetmeliği, Türkiye Bayındırlık ve İskan Bakanlığ $1,2008$.

[6] Department of Ancient Monuments and Museums

[7] http://earth.google.com

[8] Aktaç, T., Restoration of Earthen Building on Zahra Street-Lefkoşa, Kerpiç08-Learning from earthen architecture in climate change International Conference, Cyprus International University, Lefkoşa/Northern Cyprus, 4-5 September 2008.

[9] www.seneruygulama.com.tr

[10] Gedik, Z.G., Unver, R., Küçükkılıçözcan, E., Turkish Regulations on Energy Conservation, German-Turkish Workshop on Sustainable Energy, TUBITAK MRC, Gebze, Kocaeli/Turkey, 2008.

[11] Işık, B., Çakır, S., Hacaloğlu, A., Energy Efficient Building in Cyprus: Proposing earthen envelop \& steel interiors, Kerpiç08-Learning from earthen architecture in climate change International Conference, Cyprus International University, Lefkoşa/Northern Cyprus, 4-5 September 2008.

[12] Göçer, C., Evaluation of Adobe External Wall and External Walls Used in Frame Structure Construction Systems in terms of their Heat Permeability, Kerpiç08-Learning from earthen architecture in climate change International Conference, Cyprus International University, Lefkoşa/Northern Cyprus, 4-5 September 2008.

[13] Yılmaz, Z., Manioğlu, G., Evaluation of Thermal Performance of Gypsum Stabilized Adobe (Alker) for a School Building in Istanbul, Kerpiç05-Living in Earthen Cities, ITU, Istanbul/Turkey, 6-7 July 2005.

[14] Turkish Standards TS 825, Rules of Heat Insulation in Building, 1998.

[15] Turkish Standards TS 2164, Principles For the Prefaration of the Projects of the Central Heating Systems, 1983.

[16] Eğitim Notları-29 Is1 Yalıtım Hesap Örneği, akmyo.kocaeli.edu.tr 